\title{
Donald J. Trump and the Politics of Democratic Dysfunction
}

\author{
Cary Fraser
}

On June 16, 2015, Donald Trump launched his Presidential campaign with great fanfare and his press conference presaged the vitriolic campaign that he subsequently conducted in pursuit of the Presidency. That announcement provided ample evidence of his durable capacity for the selfpromotion that had defined his career as a national media personality with his own television show. Beyond the display of his talent for self-promotion, Trump emphasized two central campaign themes in his announcement - bigotry directed at Mexicans and other Latin American migrants; and, his open contempt for, and his willingness to disparage, the American political class in his speech. ${ }^{1}$ The intemperate tone of his remarks reflected the observation of Richard Hofstadter:

We are all sufferers from history, but the paranoid is a double sufferer, since he is afflicted not only by the real world, with the rest of us, but by his fantasies as well. ${ }^{2}$

The day after Trump announced his candidacy, June 17, 2015, Dylan Roof killed the pastor and eight other members of the Emanuel African Methodist Episcopal Church in Charleston, South Carolina who were engaged in a mid-week Bible study session. Roof was apparently of the view that his actions would be able to trigger a race war. ${ }^{3}$ In effect, Roof - like Trump - was "a double sufferer" - in the language of Hofstadter - and his profane fantasies resulted in the desecration of the sacred sanctuary that the church represented for members of the African American community in Charleston.

The coincidence of Trump's announcement and Roof's heinous crime were signals of an emerging crisis of the American political system. It was evident that racist and xenophobic rhetoric and racist-motivated violence had again moved to the center of American national politics and across generations. Roof's cold-blooded act of murder was both traumatic in the moment - and revelatory of the depth of racial hatred that has often found a safe harbor in American political culture. It was also a window into the imagination of a younger generation of Americans who have been influenced by the persistence of the ideology of white supremacy that has been a facet of American life and culture for several centuries. ${ }^{4}$

On the other hand, Trump's rhetoric defined the spirit of his Presidential campaign and his commitment to destabilizing the American political system. His campaign was thereafter systematically infused with currents from the basket of bigotry - racism, misogyny, religious discrimination, and xenophobia - that has contributed to the shaping of American social and 
political life. The overt use of bigoted rhetoric - both heated and subtle; the deliberate provocation of an atmosphere of fear and anxiety around election campaigns; and threats of violence by and to political candidates have been recurrent features of American politics. Trump adopted that complex mix of intimidatory tactics allied with a vitriolic dose of misogyny articulated in the orchestrated chants of "lock her up" directed at his opponent, Hillary Clinton, during the rallies he organized over the course of his 2016 campaign. ${ }^{5}$

Trump's strategy in 2016 was also shaped by the contours of the electoral platforms adopted by Republican candidates since Richard Nixon's successful 1968 Presidential campaign. Nixon had embraced the "Southern strategy" through which the former Democratic/segregationist stalwarts from the South - Strom Thurmond, Jesse Helms, and their allies - switched their considerable popular support in the region to the Republican party. ${ }^{6}$ For these Southern leaders, leaving the Democratic fold to join the ranks of the Republican party was a demonstration of their profound disappointment that arose from their disagreements with the Democratic KennedyJohnson administrations that had enacted major Civil Rights Legislation - including the Voting Rights Act of 1965. These reforms were designed to bring the Southern states into compliance with the efforts to move America away from the discredited "Jim Crow" regime, which had been institutionalized over the American landscape after the Plessy v. Ferguson decision of the Supreme Court in 1896. The Plessy decision opened the path to the diffusion of a culture of racial segregation and policies of political oppression directed at racial and ethnic minorities - underpinned by both random and organized violence that deprived minority voters of their voting and other citizenship rights.

In 1964, the Barry Goldwater campaign had provided an early signal of the Republican party's shift towards the Southern strategy in the Goldwater presidential campaign platform. In an astute commentary on the platform the New York Times adverted to the long-term significance of the Republican party's strategy in the 1964 campaign:

In its fundamental rejection of progressive Republicanism, the Goldwater platform is neither forwardlooking nor conservative. On the contrary, it gives a new and reactionary look to the G.O.P. It is ominously radical in its willingness to break with all that is good about the past, and it is dangerously reckless in its demand for measures that will exacerbate differences and conflicts at home and abroad. ${ }^{7}$

Nixon's strategic realignment of the Republican party in the 1968 campaign was the platform upon which Republicans pivoted to emerge as the champions of political, economic, social, and "racial" conservatism following the processes of political and constitutional reform that had gained ground after the Brown v. Board of Education in 1954. The strategy was also - in a more profound sense - a repudiation of the Eisenhower administration in which Nixon had served as Vice President. President Dwight Eisenhower in 1957 confronted a challenge from a Southern Governor, Orval Faubus in Arkansas when the latter attempted to derail the desegregation of the High School in Little Rock. Eisenhower sent troops to Arkansas to ensure that Faubus would accept the authority of the United States Supreme Court and its Brown v. the Board of Education decision of 1954. Eisenhower's action was a signal that he was prepared to endorse a gradual approach to implementing educational desegregation.

The Little Rock crisis was also an evocation of the memories of the American Civil War and Reconstruction when the Federal government sent troops into the South to protect African Americans from Confederate retribution. It was a decisive precedent that set the stage for Eisenhower and his successors to use military force to rout segregationist opposition to the 
Brown decision. Just as important, Eisenhower's action occurred in the centennial year of the Scott v. Sandford decision of the United States Supreme Court which had stipulated that people of African descent were not considered as eligible citizenship under the American constitution. That decision was one of the catalysts for the eruption of the American Civil War in 1861.

In 1957, President Eisenhower also signed the Civil Rights bill passed by Congress which established the Civil Rights Division in the Justice Department. It was the first major federal Civil Rights legislation promulgated in the 20th century. The bill authorized federal officials to prosecute efforts by individuals who sought to deprive another citizen of his/her right to vote. In addition, the 1957 legislation established a six-member Civil Rights Commission to which was delegated the responsibility to investigate allegations of voter infringement. In effect, the Eisenhower administration had adopted a bipartisan approach at the federal level to the issue of civil rights - in collaboration with Democrats under the leadership of the Senate Majority leader, Lyndon B. Johnson. Further, in 1957, Vice President Nixon had attended the independence celebrations of Ghana and in a report to President Eisenhower on his trip to Africa, Nixon indicated that - "We cannot talk equality to the peoples of Africa and Asia and practice inequality in the United States." In effect, in 1957, the Eisenhower administration was placing the authority of the Executive Branch behind the Supreme Court's unanimous decision in 1954 to articulate in constitutional terms the relationship between equal access to education and citizenship equality.

Eleven years later, the 1968 election campaign for the Presidency provided the opportunity and context for Richard Nixon to shift his ground. As the New York Times had anticipated in 1964, the Republican platform for the Goldwater campaign against President Lyndon Johnson had opened a major ideological rift within the Republican party which followed the defeat of Nelson Rockefeller from New York - the most prominent advocate for the Civil Rights struggle within the Republican party. Goldwater's triumph over Rockefeller represented a major shift in the center of gravity in the Republican party. ${ }^{9}$ Thereafter, the Republican party's leadership (except for Trump in 2016) has been selected primarily from the American West which provided validation for Nixon's 1968 Southern strategy for the realignment of American politics.

In effect, in his 1964 campaign against Johnson, Goldwater had initiated the Republican efforts to court segregationist voters and other conservatives who were uncertain about and/or hostile to the Civil Rights movement. ${ }^{10}$ Before the 1964 election, the domestic backlash against the Civil Rights struggle and political polarization had intensified amid the assassinations of Medgar Evers and President Kennedy in 1963. Later, the murder of Malcolm X in 1965 and the assassinations of Martin Luther King, Jr. and presidential aspirant Robert Kennedy in 1968, deepened the levels of polarization that thereafter consumed American political life. Thus, by 1968, American politics was trapped in the vortex created by the escalating conflicts over efforts to move beyond the centuries-long tradition of human inequality that had sanctified the system of slavery, racist oppression, and the politics of compromised citizenship over the course of American history since 1776.

Nixon's victory had vindicated his decision to limit his enthusiasm and support for civil rights and the alliance with Southern segregationists that allowed the Republican party to win the White House. ${ }^{11}$ The 1968 election thus represented the Republican party's shift from its status as the party of Abraham Lincoln to that of the party of Richard Nixon and the Southern strategy - a strategy that paid signal dividends in terms of the Republican electoral fortunes thereafter.

In 2016, Donald Trump strategically embraced both the Nixon Southern strategy of 1968 and the rhetoric of rage popularized by the anti-establishment segregationist Democrat George 
Wallace who also ran for the Presidency in 1968 under the banner of his personal campaign vehicle - the American Independent Party. ${ }^{12}$ Nixon's campaign strategy in 1968 had allowed him to split the Democratic party along regional lines and to limit the appeal of George Wallace's crude racist platform on the national stage. Trump's presidential campaign in 2016 was based upon the utilization of the rhetoric of political polarization and his targeting of the first African American President - Barack Obama - as the cause of "American decline." That critique allowed him to advance the claim that he should become the President who could "Make America Great Again" by embracing the legacies and rhetoric of both Richard Nixon of California and George Wallace of Alabama.

The Nixon-led Republican political realignment of 1968 was followed in the 1970s and 1980s by the emergence of the "Moral Majority" which included conservative Protestant and Catholic communities that moved to embrace the Republican party after the 1973 Roe v. Wade decision on abortion. ${ }^{13}$ Further consolidation of the growing conservative movement was temporarily disrupted by the 1974 resignation of Nixon in response to the impeachment proceedings. However, Jimmy Carter's single term (1977-1981) was defined by the increasingly conservative tenor of American politics that would ultimately open political space for a reinvigorated Republican party. In 1980, Ronald Reagan emerged as the unifying figure around which these conservative communities both religious and secular - coalesced to win the Presidential election in that year. ${ }^{14}$

The Reagan conservative "revolution" had arrived and one of its major priorities was a commitment to shrink and redefine the New Deal state that had emerged from the Great Depression and the Second World War under the leadership of the Franklin D. Roosevelt and Harry Truman led administrations. The key achievements of the New Deal state had included the expansion of the powers of the federal government to engineer a multi-decade program of sustained economic growth, the expansion of the national education system, and increasing innovation in agricultural, industrial, and commercial development.

Reagan and his colleagues were very interested in reversing some of the changes that had been introduced by the New Deal state, including limiting the power of labor unions which had become a powerful constituency within the Democratic party. ${ }^{15}$ In effect, after almost five decades (1932-80) of Democratic domination of American politics the Reagan administration marked a Republican return to the pursuit of a politics of deference to oligarchic privilege that had defined America in the early 20th century. During that era, the Teapot Dome corruption scandal had rocked the Republican Warren G. Harding administration and, later in that decade, the Republican President Herbert Hoover had overseen the economic collapse that morphed into the Great Depression which led to two decades of Democratic administrations.

Dwight Eisenhower's two-term administration (1953-61) marked a brief revival of Republican fortunes. His tenure was defined by his moderate conservatism, his support for education and science as platforms for American economic and military innovation and dynamism during the Cold War era, and his public willingness to respect and champion the principles and precedents of American governance including respect for the courts.

Nixon's focus upon foreign policy and his partnership with Henry Kissinger which covered the negotiations to end the Vietnam War, the opening to China, the search for détente with the Soviet Union, and confronting the escalating tensions in the Middle East arising from the Palestinian turn to armed struggle and Israel's escalating conflicts with its Arab neighbors - had burnished his reputation during his Presidency. However, his evident lack of scruple triggered the Watergate scandal and his resignation in 1974 during his second term tarnished the Republican 
brand. Despite his embrace of the Southern strategy, Nixon was careful to maintain a pragmatic stance on the need to remedy the historical disadvantages confronted by the African American community and was recognized as a key advocate for "affirmative action" as a policy to expand opportunities for American minorities. ${ }^{16}$

Given this checkered history of Republican politics over the course of the 20th century, Reagan presented himself as a symbol of Republican revival in 1980 and a champion of American conservatism in economic, political, and religious-cultural terms. In the 1980 campaign, Reagan traveled to Neshoba County, Mississippi to launch his campaign with a speech on "States Rights" in an area where three civil rights activists - James Chaney, Andrew Goodman and Mickey Schwerner were slain by the Ku Klux Klan in 1964. Like his predecessor Richard Nixon, Reagan in 1980 sought to reassure voters that he embraced the Southern strategy as integral to the Republican national platform. In his re-election campaign in 1984, he again traveled to Mississippi to reassure the South that it would rise again. ${ }^{17}$

However, the Iran-Contra scandal and the investigations into the conduct of American foreign policy in the Persian Gulf and Central America brought an end to the illusion of Reagan's ability to ensure the uncontestable dominance of the Republican brand in American politics. Reagan's Vice President, George H.W. Bush, was elevated to the Presidency in the 1988 election in the wake of a virulently racist campaign - featuring "Willie Horton" - a convict who absconded and raped a woman - to cast his Democratic opponent Michael Dukakis as "soft-on-crime." The coded appeal to racist hysteria in the 1988 campaign reflected the increasingly virulent politics of polarization that had been set in train by the Nixon campaign in 1968 and embraced by Reagan in 1980 and 1984. The success of the Bush campaign in 1988 again demonstrated the political appeal of the coded appeals to fear of crime in the Southern strategy and again demonstrated its appeal as a default campaign strategy for the Republican party. ${ }^{18}$

In 2016, Donald Trump enthusiastically embraced the Southern strategy to regain the White House for the Republican party. His decision to launch his campaign as a Republican candidate for the Presidency was completely logical in the context of his history in real estate investments, which had included being investigated for housing discrimination in the 1970s. Given the Republican strategy of mobilizing race for electoral campaigns, Trump's personal history provided him with the bona fides needed to persuade the Republicans that his personal animosity and bigotry toward Barack Obama could be used to good effect in the 2016 campaign. Trump's efforts to disparage Barack Obama was, and is, reflective of the currents defined by both the appeal of racist and xenophobic sentiment in American life - and which stand at the core of the contemporary version of the Republican party. ${ }^{19}$

Those sentiments cannot be discounted from the calculus of Republicans who accepted Trump as the Presidential candidate in 2016. Mitch McConnell, the Senate Republican leader, who had publicly announced in 2009 that he would aspire to limit Obama to a single term as President had sent a very clear signal that he was deeply uncomfortable with the reality of an Obama presidency. McConnell had been elected to the U.S. Senate from Kentucky in 1984 during the Reagan era - and his early political career was shaped by the Nixon-inspired realignment as well as his service in the Ford administration in the wake of Nixon's impeachment. In effect, McConnell's career can be considered as evidence of the durability of Nixon's political legacy.

As the current Senate Majority leader from Kentucky - a former slaveholding state McConnell has evolved as a key player in maintaining the viability of the Southern strategy's role in building national Republican electoral coalitions. His role was magnified in recent months by 
the control he demonstrated in ensuring that the trial that followed the impeachment of Donald Trump by the House of Representatives did not result in the removal of Trump from office. Trump's use of racist and xenophobic rhetoric in his Presidential campaign was acceptable to the Republican party. On the other hand, the Republican party's response to Representative Steve King, a Republican from Iowa who made a career of making blatantly racist statements, was to discourage him from remaining in Congress. ${ }^{20}$

For both McConnell and Trump, Obama's Presidency was, it would seem, a powerful indication of the growing appeal for a politics of diverse representation that could move American politics beyond Nixon's 1968 strategy that has helped to polarize American politics in recent decades. In that context, Trump's announcement of his candidacy in June 2015 may have provided McConnell and other Republicans with an opportunity to restore an alliance that had worked effectively in the cases of Nixon and Reagan - Trump as a non-Southern candidate for the Presidency willing to campaign using the inflammatory rhetoric that has informed the appeal and politics of American conservatism. Jeff Sessions from Alabama, who was the first sitting Senator to endorse Trump's presidential campaign, was selected as the Trump presidential campaign manager and that choice was a signal of Trump's embrace of the Southern strategy as a cornerstone of his campaign and his future administration.

Donald Trump's 2016 strategy thus followed the precedent adopted by his Republican predecessors - Richard Nixon, Ronald Reagan, George H. W. Bush, and George W. Bush - all of whom extolled Conservatism as a philosophy of governance while exploiting covert and overt appeals to racist tropes in American life which could help to pave the way to the Presidency. In effect, Donald Trump's victory in 2016 - after having won a minority of the popular vote but a majority within the Electoral College - was but another successful demonstration of the effectiveness of the Southern strategy as a path to the Presidency embraced by the Republican party since $1968 .^{21}$

However, Trump's campaign illustrates another phase in an evolving multi-decade crisis at the core of American democratic culture and its institutions of governance. In 1954, the United States Supreme Court delivered a relatively rare unanimous decision - Brown v. Board of Education which invalidated the legal justification of segregated public education and clearly spelled out the reasons for so doing by asserting:

Today, education is perhaps the most important function of state and local governments. Compulsory school attendance laws and the great expenditures for education both demonstrate our recognition of the importance of education to our democratic society. It is required in the performance of our most basic public responsibilities, even service in the armed forces. It is the very foundation of good citizenship. Today it is a principal instrument in awakening the child to cultural values, in preparing him for later professional training, and in helping him to adjust normally to his environment. In these days, it is doubtful that any child may reasonably be expected to succeed in life if he is denied the opportunity of an education. Such an opportunity, where the state has undertaken to provide it, is a right which must be made available to all on equal terms. ${ }^{22}$

The Brown decision was a decisive refutation of the separate but equal regime that had emerged out of the Supreme Court's Plessy v. Ferguson decision (1896). The Plessy decision had asserted the disingenuous proposition that racial segregation in public transport was not unconstitutional since:

Legislation is powerless to eradicate racial instincts or to abolish distinctions based upon physical differences, 
and the attempt to do so can only result in accentuating the difficulties of the present situation. If the civil and political rights of both races be equal, one cannot be inferior to the other civilly or politically. If one race be inferior to the other socially, the Constitution of the United States cannot put them upon the same plane. $^{23}$

The Plessy decision assumed that "social inferiority" - caste by another designation - was outside of the Constitution's commitment to equality of citizenship. In the unanimous 1954 Brown decision, the Supreme Court asserted the principle that equality of access to education offered the possibility of citizenship equality for disadvantaged groups within American society. In effect, the Supreme Court was both explicitly repudiating the Plessy v. Ferguson decision and articulating an intellectual strategy for invalidating notions of superior and inferior races within American life.

This radical proposition within the American context emerged in a post-1945 environment where the United States confronted the paradox that Justice Robert Jackson - a member of the US Supreme Court - had served as the Chief Prosecutor at the Nuremberg War Tribunal which had passed judgments upon Nazi war criminals who had engaged in genocide. In addition, Chief Justice Earl Warren, - prior to his appointment to the Supreme Court - had been instrumental in organizing the internment of people of Japanese descent in camps in the United States during the Second World War. Against the immediate backdrop of the wartime detention of Japaneseorigin communities in the USA and the horror of the Holocaust inflicted upon Jewish and other ethnic communities in Europe, it was evident that the United States would face scrutiny over its treatment of its minority populations after the defeat of the Nazi regime.

In the immediate aftermath of the Second World War, the United States was also confronted by the report - An American Dilemma - on its domestic racial regime that had been compiled by a team led by the Swedish social scientist, Gunnar Myrdal. The report commissioned by the Carnegie Corporation was a comprehensive review of American race relations which painted a damning picture of the gap between the reality of compromised citizenship for African Americans and the official rhetoric of American championship of democracy in the struggle against the Nazi and other Fascist regimes. In his Foreword to the report, Frederick Keppel of the Carnegie Corporation stated:

When the Trustees of the Carnegie Corporation asked for the preparation of this report in 1937, no one (except possibly Adolf Hitler) could have foreseen that it would be made public at a day when the place of the Negro in our American life would be the subject of greatly heightened interest in the United States, because of the social questions which the war has brought in its train both in our military and in our industrial life. It is a day, furthermore, when the eyes of men of all races the world over are turned upon us to see how the people of the most powerful of the United Nations are dealing at home with a major problem of race relations. ${ }^{24}$

Keppel clearly understood that the Second World War and the American quest for international leadership would be evaluated within the context of credible and serious changes in the American "Jim Crow" regime - given the Nazi regime's murderous propensities on the issue of "racial" and religious differences.

In sum, the Brown decision marked the opening of an effort - led by the Supreme Court to chart a new course for American life and its political culture. It was a decisive break, both in jurisprudence and official rhetoric, with the politics of racial and citizenship inequality that had defined American life from its founding in the late eighteenth century. According to Judith Shklar: 
There is no notion more central in politics than citizenship, and none more variable in history or contested in theory. In America it has in principle always been democratic, but only in principle. From the first and most radical claims for freedom and political equality were played out in counterpoint to chattel slavery, the most extreme form of servitude, the consequences of which still haunt us. The equality of political rights, which is the first mark of American citizenship, was proclaimed in the accepted presence of its absolute denial. Its second mark, the overt rejection of hereditary privileges, was no easier to achieve in practice, and for the same reason. Slavery is an inherited condition. ${ }^{25}$

The Supreme Court in 1954 had asserted an intellectual quality of leadership that was a challenge to American political leaders.

In effect, the Court had cut the Gordian knot of compromised citizenship experienced by disadvantaged communities within the American body politic through the assertion of the centrality of education to "good citizenship." In light of the human costs and consequences of the American civil war which had resulted from the fundamental problem of governing a society - "half-slave, half-free" - the Supreme Court in 1954 demonstrated the courage that was absent in the other two branches of the political system. As a consequence, every President since Dwight Eisenhower has been expected to provide some level of leadership to move American society beyond its long-standing legacies of bigotry and the conundrum of citizenship inequality in a quasi-democratic polity.

Donald Trump has decisively broken with that post-1954 tradition. His 2016 campaign rhetoric and his subsequent approach to governance have both reflected a commitment to revitalizing the politics of citizenship inequality in American society. His willingness to publicly excoriate immigrants including Mexicans and Central Americans - as well as his targeted attacks on his Republican 2016 rivals Marco Rubio and Ted Cruz - has illustrated his efforts to stigmatize people of Hispanic origin who now represent the largest ethnic minority community in America. These tactics were reminiscent of the xenophobic sentiment that animated anti-Catholic and antiimmigrant sentiment in the mid-19th and early-20th century eras in American politics.

Trump also seems interested in retracing the footsteps of Woodrow Wilson, the Democratic President who worked assiduously to ensure the consolidation of the Jim Crow regime in the aftermath of the 1896 Plessy v. Ferguson decision by the Supreme Court. Wilson's enthusiasm for white supremacy was reflected in the White House screening of the film The Birth of a Nation - a film notorious for its role in legitimizing the anxieties and resentments of the post-Civil War South. ${ }^{26}$ Wilson was born in Virginia in 1856 and grew up in the household where his father was a Presbyterian minister who served congregations in Georgia and South Carolina. He pursued an academic career and served as the President of Princeton University before being elected as Governor of New Jersey and became the President of the United States in 1913.

Wilson's enthusiasm for the film was undoubtedly a reflection of both his southern roots and his enthusiasm for the Jim Crow regime as a "Bourbon restoration" in the American context. However, his hosting of the film in the White House may have also been a gesture aimed at repudiating Theodore Roosevelt's invitation to the African- American notable Booker T. Washington to dine at the White House in $1901 .^{27}$

In the twenty-first century, Trump demonstrated a profound hostility to the idea of an African-American President - Barack Obama in the White House - as another affirmation of "progress" in dealing with the tortuous politics of race in American society. Trump's anxiety about the issue was manifest during Obama's tenure and he remains profoundly conscious that Obama's Presidency will provide a benchmark for the evaluation of his own tenure as President. 
Further, Trump's campaign and his tenure since assuming office in January 2017 - including his early efforts to block citizens from Islamic countries being admitted to the US - reflected the emphasis upon expanding his commitment to religious discrimination. In turn, his disparagement of the political class has been redirected specifically at the Democratic Party and the Republicans who have distanced themselves from his administration. As a consequence, Trump has consistently sought to erode the norms and traditions of constitutional governance that have evolved since the founding of the American state. In order to accomplish these goals, Trump has actively sought to expand the role and power of the Presidency in the American constitutional order and his actions have led to his impeachment - though the Republican-controlled Senate has been able to block any effort to have him removed from office. ${ }^{28}$

In sum, Trump has demonstrated a flawed understanding of the constitutional order that had been created by the very sophisticated thinkers who designed the framework of American governance as a federal republic. That system consists of the three branches of the federal government - the executive, the legislative, and the judiciary - and was designed to prevent the concentration of power in any single branch that could undermine the self-determination of the citizens. Further, the self-determination of citizens is expressed through regular elections for both the Executive and Legislative branches which impose accountability upon the "would-be rulers" through the electoral process. In effect, representative government required the empowerment of citizens as electors and members of the body politic who could serve as the ultimate mechanism for oversight of elected officials - including the President - through the conduct of regularly scheduled elections.

These fundamentals of governance in the American Republic have proven to be remarkably resilient - as both process and principles of governance - in the establishment and consolidation of the American experiment in representative government. Originally conceived as a system of limited representation with suffrage reserved for citizens endowed with the right to vote based upon property qualifications, the American republic has evolved from an oligarchic system to one based - in principle - on universal suffrage in the second half of the 20th century with the passage of the 1965 Voting Rights Act. The evolution of the American political system from Oligarchy to Democracy has never been smooth and - in the contemporary context - it has entered a period of dysfunction during which the contest of oligarchy versus democracy has been revived in its most fundamental forms under the Trump administration.

Trump's 2016 campaign and his electoral victory based upon the loss of the popular vote have informed his tenure since assuming office in January 2017. His early efforts at preventing citizens from Islamic countries from being admitted to the US expanded the realm of his commitment to bigotry on the grounds of religion. In turn, his disparagement of the political class has been redirected specifically at the Democratic party through his efforts to defy and dismiss Congressional oversight. ${ }^{29}$ Trump has also sought to question the functioning of the courts and law enforcement agencies, including the Federal Bureau of Investigation. These provocative steps have illustrated his systematic efforts to erode the norms and traditions of constitutional governance and the role of the Presidency in the American constitutional order. In effect, Trump has triggered a perception of American democracy as an increasingly dysfunctional system and has sought to expand his discretionary authority at the expense of the other branches of government - including the Courts.

It is arguable that - in the American experience - the politics of dysfunction serves as a precursor of intense struggles over the future of the society and the politics of representation 
therein. It is also important to note that the redefinition of citizenship in American political life has been at the root of the periodic dysfunction that has continually reshaped American politics and society. The American Revolution had changed the status of the settlers in the British colonies - they had transformed themselves from subjects of the British monarchy into citizens of the American Republic. In the process of creating the new Republic, the founding generation had established the centrality of white male citizenship in the construction of the political order.

A powerful illustration of the consolidation of white male privilege is to be found in the correspondence between John Adams and his wife, Abigail Adams.

In 1776, Abigail Adams famously pleaded with her husband to:

"Remember the Ladies" in drafting the nation's new code of laws. Warning him against putting "unlimited power into the hands of the Husbands" because "all Men would be tyrants if they could," she promised that American women would "not hold ourselves bound by any Laws in which we have no voice, or Representation.” John Adams replied by telling her thanks, but he preferred male privilege: "We know better than to repeal our masculine systems." The masculine systems established by the framers meant that women didn't get the vote until 1920, still earn a fraction of what men earn, and remain subject to a state asserting control over their bodies that it doesn't assert over male bodies. ${ }^{30}$

This validation of the "masculine systems" set the stage for a constitutional order that ensured white male privilege and entitlement to citizenship as a right. This initial refusal to establish the right of women to vote was confronted by the suffragette movement which mobilized women to organize petitions and protests to secure the passage of the 19th amendment to the American Constitution in 1920. That amendment established the democratic right of women to assert their citizenship rights by being empowered to exercise the franchise.

However, as the 2016 Presidential election demonstrated, the fierce opposition to Hilary Clinton's candidacy by the Republican party seems to have arisen, in part, from a desperate desire to prevent further challenges to the repeal of the "masculine - systems" about which John and Abigail Adams had debated. Clinton was the first female candidate for President from one of the major parties in America and it was evident that the tradition of white male privilege faced its greatest threat from her candidacy - especially since Barack Obama had shattered the idea that the Presidency was an exclusive white male privilege. Obama won two terms in office and provided a quality of leadership necessary to stabilize the economy after the reckless adventurism of the Republican administration of his predecessor, George W. Bush, whose tenure had paved the way to the most severe economic crisis since the Great Depression of the 1930s. Obama's electoral successes and his policy accomplishments have opened the door for debates about the need to open the pathways to the Presidency for all Americans - without regard to race and gender.

However, his tenure had also produced a backlash among sections of the American population - including Donald Trump who has proven himself to be a persistent critic of Obama. The latter's electoral success has further eroded the "legitimacy" of the "white supremacist illusion" that has been a cornerstone of American politics. In a very perspicacious commentary about the possible future of the young republican Thomas Jefferson recognized that the legacies of history and its tradition of citizenship inequality would weigh heavily on its future. In his Notes on the State of Virginia (QUERY XIV, LAWS 1782), Jefferson had observed that:

Deep rooted prejudices entertained by the whites; ten thousand recollections, by the blacks, of the injuries they have sustained; new provocations; the real distinctions which nature has made ... will divide us into parties, and produce convulsions which will probably never end but in the extermination of the one or the 
other race. To these objections, which are political, may be added others, which are physical and moral. ${ }^{31}$

Jefferson's observation about the long-term consequences of slavery for American political life was very perceptive and his turn of phrase reflected the acute sense of psychological dislocation that had occurred in American culture through the practice of "racialized" slavery. That psychological dislocation has continued into the contemporary context of the 21 st century. As a result, the election of Donald Trump as President in 2016 with the support of a Republican party dedicated to the politics of privilege and citizenship inequality has again brought to the fore a crisis of the American political order around the issues of race and citizenship.

Trump's campaign and his naked appeals to bigotry to win the presidential election were unleashed against the backdrop of the increasing diversification of immigrants - from Asia, Latin America, and Africa - moving into American society. The empowerment of new constituencies through the expansion of both voting rights and access to education that accompanied the Civil Rights struggle of the mid-20th century and the immigration reform of the 1960s has decisively shifted the trajectory of American society. Over the next several decades, the USA will face the unprecedented challenge of having to come to terms with the reality that it has a population that is so diverse that it may no longer be a white majority society. ${ }^{32}$ Instead, it is likely to become a society of multiple minorities and the essentialism of the ethos of white supremacy that has hitherto defined American life will be a source of continued tensions among some groups - a development that Trump and his eminence grise - Steve Bannon - exploited to great effect in the 2016 campaign.

Simply put, the dark shadows of American patriarchy, religious bigotry, and white supremacist ideology and policies, have imposed a conundrum that has triggered dysfunction on several occasions across American history - the Civil War, the Jim Crow regime, anti-immigrant and antiCatholic sentiment, the Civil Rights Struggle, and a virulent culture of misogyny - in American life from its founding.

In August 2017, the white supremacist march and disturbances in Thomas Jefferson's "neighborhood" - Charlottesville, Virginia - was an ironic tribute to Jefferson's perceptiveness of the future of American race relations. In this context, Dylan Roof's premeditated murder of the black parishioners and their pastor in Charleston in 2015 was but a harbinger of the reenactment of the profound tensions around the politics of white supremacy and citizenship that have animated American politics since the founding of the USA.

Trump's presidential campaign had exacerbated and exploited the Republican hostility to the Obama administration and its success in restoring a semblance of normality to American politics after the misadventures of the George W. Bush administration. Since his inauguration, Trump has employed a strategy of governance focused upon confrontation and partisan polarization in the effort to limit constitutional accountability in his exercise of the powers of the Presidency. ${ }^{33}$ A crisis point has already been reached and Trump has been impeached by the House of Representatives which has a Democratic majority. Though the Republican Majority in the Senate has prevented his removal from office after a trial, it is evident that Trump remains a profound threat to both the American constitutional system and the tenuous stability of the wider international system.

Against this backdrop of domestic polarization and gratuitous confrontation at home and abroad, Trump's foreign policy agenda of "Making America Great Again” (MAGA) has given pause to European and NATO alliance partners, and produced a comic-opera suite of summits on the strategic dilemma posed by North Korea's nuclear and missile development programs. 
Trump has also forced a confrontation on trade with China in a misguided effort to derail China's rise as a global power. Other policy choices, including the assassination of Qasem Soleimani - the brilliant Iranian strategist who forged a network of alliances that has reshaped the dynamics of the Persian Gulf and the Middle East - have become a catalyst for both short- and long-term instability in the Middle East and the Persian Gulf. In brief, the Trump presidency has projected an image and has adopted policies that suggest both incoherence and instability at home and abroad.

In the $21^{\text {st }}$ century, the Trump administration and the Republican party seems to be struggling mightily to find an ideological rationale for the legitimation of "white minority rule in the future." The emergence of an "apartheid-based" vision for a system of representative government has been implicit in the Republican gerrymandering of electoral representation since the 2010 elections - two years after the election of Barack Obama, the first African-American President. ${ }^{34}$ The electoral victories of that year provided the Republicans with control over redistricting in the majority of states and also announced the arrival of the Tea Party movement as a reactionary force in the Republican party and the wider arena of American politics.

Trump's rhetoric and policies have also exacerbated a long-term predicament for American politics - a crisis of Presidential leadership. Every President since Lyndon Johnson has confronted crises (several self-inflicted) that have challenged the capacity of Presidents to accomplish their goals. Johnson stepped into the quagmire in Vietnam and lost the election of 1968. Nixon conspired his way into Watergate and was forced to leave the White House due to leaks from the Federal Bureau of Investigation. Ford's truncated Presidency was marked by the unpopular pardon for Richard Nixon and the collapse of South Vietnam leading to a humiliating American withdrawal from that country. Carter was overcome by the Iranian Revolution that opened a new era in the Middle East, the Persian Gulf, and South Asia as Islamic radicalism revealed its latent power.

The Reagan administration collapsed under the weight of the Iran-Contra scandal that reflected the flawed strategies of containment in dealing with non-European revolutionary regimes - a lesson that had to re-learned after the failure in Vietnam. George H.W. Bush confronted the recession triggered by the collapse of the Savings and Loan Industry and a lack of sufficient charisma to overcome the challenge from Bill Clinton - despite leading a coalition of countries that reversed Iraq's invasion and occupation of Kuwait. Bill Clinton's questionable judgment was revealed by the Rwanda genocide, his tentativeness in dealing with the disintegration of Yugoslavia, and the patent absurdity of a President having an affair with a White House intern. George W. Bush was overcome by the decision to wage a War on Terror that exposed his lack of perspicacity in foreign affairs and poor strategic decision-making in launching two wars in Afghanistan and Iraq. Obama faced the rise of the insurgent Tea Party and the Republican party's adoption of its version of anti-Reconstruction politics in the wake of Obama's election. Further, the Obama administration's unfortunate decision to participate in the 2011 overthrow of Muammar Gaddafi in Libya replicated the mistakes of his predecessor in Iraq and contributed to the Republican campaign that derailed Hilary Clinton's Presidential bid against Donald Trump.

This multi-decade crisis arguably had its origins in the assassination of John Kennedy in November 1963 in the midst of the growing challenge to white supremacy in American life that was mounted by the civil rights movement. ${ }^{35}$ The escalation of the Civil Rights struggle had occurred in a context where America was waging war in Vietnam. After his predecessor's assassination, President Lyndon Johnson - faced with a domestic crisis of civil rights - expanded 
the war in Vietnam as a way of presenting himself as a decisive President in the 1964 Presidential campaign. The Civil Rights Act was passed on July 2, 1964 and the Gulf of Tonkin resolution supporting the Johnson administration's strategy of escalating the war was approved on August 7 , 1964 - providing Johnson with the opportunities to demonstrate his command of both domestic politics and foreign policy in the months preceding the 1964 election. Johnson's use of foreign policy to advance domestic agendas was not singular as Richard Nixon resorted to a similar tactic in the 1968 election campaign when he sought to portray Lyndon Johnson as an ineffective President:

And I say to you tonight that when respect for the United States of America falls so low that a fourth-rate military power, like North Korea, will seize an American naval vessel on the high seas, it is time for new leadership to restore respect for the United States of America. [Richard M. Nixon Presidential Nomination Acceptance Speech Republican National Convention Miami Beach, Florida August 8, 1968] ${ }^{36}$

It is a profound irony that Donald Trump adopted as an early priority an initiative to devise a strategy for getting North Korea to dismantle its nuclear weapons program. This initiative has since been abandoned by North Korea - reflecting the reality that North Korea is no longer a fourth-rate military power and is quite capable of withstanding American pressures. However, the negotiations were effective as a distraction from the harsh anti-immigrant rhetoric and xenophobic policies adopted by Trump amidst his failure to get the Mexican government to agree to build "the wall"- as he had rhetorically advocated in his 2016 election campaign. Trump's diplomatic strategy towards North Korea has done little to create an image of a hero in the White House - especially in a context where Kennedy had been able to negotiate the withdrawal of Soviet nuclear missiles in Cuba in 1962.

Trump's embrace of anti-immigrant and racist rhetoric has become a defining characteristic of his term in office and his personal appeals to bigotry recall the temper of American politics prior to the outbreak of the American Civil War. The electoral campaign and his tenure in office thus far have derailed American politics and created an image - and a powerful current - of democratic dysfunction. He has revitalized the anger that has infused American debates around race, immigration, and unequal citizenship which, in turn, has informed agonizing periods of American political life - including the Civil War, the Jim Crow era, and the Civil Rights struggle.

In the contemporary context, it may be useful to return to the sagacity of Abraham Lincoln in a letter to Joshua Speed, dated August 24, 1855:

I am not a Know-Nothing. That is certain. How could I be? How can anyone who abhors the oppression of negroes, be in favor or degrading classes of white people? Our progress in degeneracy appears to me to be pretty rapid. As a nation, we began by declaring that "all men are created equal." We now practically read it "all men are created equal, except negroes" When the Know-Nothings get control, it will read "all men are created equal, except negroes, and foreigners, and Catholics." When it comes to this I should prefer emigrating to some country where they make no pretence of loving liberty -- to Russia, for instance, where despotism can be taken pure, and without the base alloy of hypocracy [sic]. ${ }^{37}$

Lincoln's letter preceded the Brown v. the Board of Education decision by almost a century and it signaled the intractable context within which the politics of xenophobia and racial oppression paved the way to the Civil War.

In effect, Trump, and the Republican legislators under the current leadership of Mitch McConnell of Kentucky have sought to push the boundaries of Republican legitimacy through 
the "Southern strategy" that had been effectively deployed by Richard Nixon in the 1968 election. If Nixon had discarded the nomenclature of the Republicans as the party of Lincoln by embracing Jesse Helms and Strom Thurmond in pursuit of the White House, the current Republican Party - under the leadership of Donald Trump and Mitch McConnell - has sought to refurbish the illusion of white supremacy as the culture of governance in American life. In a recent Washington Post column, the political scientist Angie Maxwell wrote:

\begin{abstract}
"Understanding the full range of the GOP's efforts in the South since Nixon clears up any confusion as to how Trump, a man whose personal life seems to violate every moral precept avowed by most Southern white conservatives, secured their unyielding allegiance. Trump has wielded the GOP's Southern playbook with precision: defending Confederate monuments, eulogizing Schlafly at her funeral and even hiring Reagan's Southern campaign manager, Paul Manafort. Trump, in many ways, is no anomaly. He is the very culmination of the GOP's long Southern strategy."38
\end{abstract}

The possibility of the polarization of American politics was anticipated by the founding generation of American leaders. ${ }^{39}$ It is arguable that the contemporary politics of polarization under the Republican party has set the stage for a return to the policies of the pre-1954 era in the 21 st century and to reverse the momentum towards genuine democracy that was promised by the passage of the Voting Rights Act of 1965. In 2013, the Supreme Court of the United States decided the case Shelby v. Holder and invalidated the federal oversight of states that had historically engaged in voter suppression. The Voting Rights Act of 1965 had established that practice to provide support for the right to vote as an index of citizenship equality.

As in the cases of Dred Scott v. Sandford and Plessy v. Ferguson, the Supreme Court in Shelby County v. Holder has reasserted, in effect, the practice and principle of compromised citizenship in American life as a constraint upon the politics of effective representation for disadvantaged communities in American life. ${ }^{40}$

In a pithy assessment of the decision, the journalist Vann Newkirk II wrote:

Ignoring that deep racial disparities do still exist in every phase of voting, especially in the precincts formerly covered by the Voting Rights Act, Roberts's legal analysis boils down to the fact that preclearance was very effective in reversing disenfranchisement, so the country no longer needs it. In her dissent, Justice Ruth Bader Ginsburg pointed out the apparent paradox of that reasoning, writing that "throwing out preclearance when it has worked and is continuing to work to stop discriminatory changes is like throwing away your umbrella in a rainstorm because you are not getting wet. ${ }^{41}$

\title{
QUO VADIS AMERICA?
}




\section{Endnotes}

1. Donald Trump's Presidential Announcement Speech | Time https://time.com/3923128/don ald -trump-announcement-speech

2. The Paranoid Style in American Politics Harper's Magazine https://harpers.org/archive/ 1964/11/the-paranoid-style-in-american-politic

3. https://abcnews.go.com/US/charlestonshoot ing-closer-alleged-gunman-dylann-roof/ story?id $=31865375$

4. https://www.nytimes.com/2018/04/18/opi nion/history-white-power.html

5. https://www.washingtonpost.com/newsthefix/wp/2016/11/22/a-brief-history-of-thelock...+

6. http://www.politico.com/magazinestory/20 14/10/barry-goldwater-lasting-legacy-112210_ Page2.html

7. The New York Times, July 13, 1964 - The Goldwater Platform, p. 28.

8. Richard Nixon, "The Emergence of Africa: Report to President Eisenhower by Vice President Nixon," Department of State Bulletin 36, 22 April 1957: 635-640.

9. https://www.politico.com/magazinestory/ 2014/10/nelson-rockefellers-last-stand-112072

10. Larry J. Sabato, How Goldwater Changed Campaigns Forever, Politico Magazine. https:// www.politico.com/magazine/story/2014/10/ barry-goldwater-lasting-legacy-112210

11. Jeremy D. Mayer, Nixon Rides the Backlash to Victory: Racial Politics in the 1968 Presidential Campaign The Historian, Vol. 64, No. 2 (WINTER 2002), pp. 351-366.

12. Maarten Zwiers, "The Whistles of George Wallace: Gender and Emotions in the 1968 Presidential Campaign ", European journal of American studies [Online], 14-1 | 2019, Online since 29 March 2019, connection on 24 March 2020. URL : http://journals.openedition.org/ejas/14454 ; DOI : https://doi.org/10.4000/ejas.14454.
13. https://talkingpointsmemo.com/cafebrief -history-of-the-christian-right; and, Jerry Falwell's Sunbelt Politics: The Regional Origins of the Moral Majority - Daniel K. Williams, The Journal of Policy History, vol. 22, No.2, 2010: pp. 125-147.

14."Worse than cancer and worse than snakes": Jimmy Carter's Southern Baptist Problem and the 1980 Election - Neil J. Young, The Journal of Policy History, vol. 26, No. 4, 2014: pp. 479508.

15. For an interesting exploration of the impact upon labor unions that resulted from the Reagan administration's efforts to limit the influence of unions in American life, see Reflections on PATCO's legacy: Labor's strategic challenges persist - RW Hurd - Employee Responsibilities and Rights Journal, 2006 - Springer.

16. Dean J. Kotlowski, Richard Nixon and the Origins of Affirmative Action, The Historian, vol. 60, No. 3, (Spring 1998), pp. 523-541.

17. Ronald Reagan in Mississippi | Mississippi Encyclopedia

18. A Lerman, VM Weaver - Race and Crime in American Politics: From Law and Order to Willie Horton and Beyond, Oxford Handbooks Online, Online Publications, 2013.

19. German Lopez, Donald Trump's long history of racism, from the 1970 s to 2019 VOX, Jul 15, 2019,

20. A Timeline of Steve King's Racist Remarks and Divisive Actions, New York Times, January 15, 2019.

21. "It's easy to forget that President Trump's surprising victory in 2016 depended more on the South than Rust Belt states. Trump won all the former Confederate states except Virginia. Combined, those 10 states provided 155 electoral votes - more than half of his total." Boris Heersink and Jeffery A. Jenkins - The Republican Party is white and Southern. How did that happen? Washington Post, February 7, 2020 . 
22. Brown v. Board of Education of Topeka (1) $\mid$ Oyez.

23. Plessy v. Ferguson | US Law | LII / Legal Information Institute.

24. F.P. Keppel, Foreword, Gunnar Myrdal - An American Dilemma: The Negro Problem and Modern Democracy, New York: Harper and Brothers Publishers, 1944 - pp. vii-viii.

25. Judith N. Shklar, American Citizenship: The Quest for Inclusion, Cambridge: Harvard University Press, 1991 - p.1.

26. Michael S. Rosenwald, The Ku Klux Klan was dead. The first Hollywood blockbluster revived it, Washington Post, August 12, 2017.

27. "Washington had a large circle of prominent supporters and friends, both African American and white. He traveled widely and his understanding of Southern politics was useful to President Roosevelt. The two men had known each other for several years before Roosevelt invited Washington to dinner at the White House on October 16, 1901, for the purpose of talking over the situation of the Republican Party in the South. On that night, Washington dined with the Roosevelt family. The next day, a firestorm of vitriol broke out from Southern whites who called for Roosevelt's impeachment. This stunned Roosevelt. While he continued to consult Washington, Roosevelt never invited him back to the White House. "TR Center Booker $\mathrm{T}$ Washington - Theodore Roosevelt Center www.theodorerooseveltcenter.org > RaceEthnicity-and-Gender > Boo...

28. Daniel W. Drezner - Immature Leadership: Donald Trump and the American Presidency - International Affairs, iiaa009, https:// doi.org/10.1093/ia/iiaa009 - Published: 04 February 2020.

29. Are We in a Constitutional Crisis? | Brennan Center for Justice www.brennancenter.org > ourwork > analysis-opinion > are-we-const...

30. America's Original Identity Politics by Sarah Churchwell, New York Review of Books Daily, February 07, 2019.
31. Notes on the State of Virginia, Query XIV - PBS www.pbs.org > jefferson > archives > documents -

32. Sabrina Tavernise, Why the Announcement of a Looming White Minority Makes Demographers Nervous, New York Times, November 22, 2018.

33. Jane Chong, Donald Trump's Strange and Dangerous 'Absolute Rights' Idea, The Atlantic February 29, 2020.

34. www.washingtonpost.com, opinions , 2016/06/17- The power that gerrymandering has brought to Republicans.

35. Jon Roper, The Contemporary Presidency: George W. Bush and the Myth of Heroic Presidential Leadership, Presidential Studies Quarterly 34, no.1 (March 2004). Roper suggests that the Kennedy administration helped to set an image of the American President as Hero "For Kennedy, his admirers, and supporters, the White House was an historic theater in which the hero should seek the center stage." p. 133.

36. http://www.4president.org/speeches/nix on1968acceptance.htm

37. www.abrahamlincolnonline.org > lincoln > speeches > speed.

38. Angie Maxwell - What we get wrong about the Southern strategy, Washington Post, July 26, 2019.

39. Lee Drutman - America is Now the Divided Republic the Framers Feared, The Atlantic, January 2, 2020.

40. The Effects of Shelby County v. Holder | Brennan Center ... https://www.brennancenter.org/our-work/ policy-solutions/effects-shelby-county-vholder.

41. Vann R. Newkirk - How Shelby County v. Holder Broke America, The Atlantic, July 10, 2018. 


\section{References}

Altman, Alex. 2017. "How President Trump Uses Fear." Time, February 9.

Ball, Story by Molly. 2016. "Donald Trump and the Politics of Fear.” The Atlantic, September 2.

Balmer, Randall. 2014. "The Real Origins of the Religious Right.” POLITICO Magazine, May 27.

Brenner, Marie. 1990. "After the Gold Rush | Vanity Fair | September 1990.” Vanity Fair, September.

Brownell, Herbert. 1991. "Eisenhower's Civil Rights Program: A Personal Assessment." Presidential Studies Quarterly 21(2):235-42.

Burk, Robert Fredrick. 1984. The Eisenhower Administration and Black Civil Rights, 1953-1961. First Edition edition. Knoxville: Univ of Tennessee Pr.

Carter, Dan T. 2000. The Politics of Rage: George Wallace, the Origins of the New Conservatism, and the Transformation of American Politics. 2 edition. Baton Rouge: LSU Press.

Chong, Jane. 2020a. "Donald Trump's Strange and Dangerous 'Absolute Rights' Idea." The Atlantic, February 29.

Chong, Jane. 2020b. "Donald Trump's Strange and Dangerous 'Absolute Rights' Idea." The Atlantic, February 29.

Dahl, Robert A. 2003. How Democratic Is the American Constitution? Second Edition. Second edition. New Haven, Conn.: Yale University Press.

Drezner, Daniel W. 2020. "Immature Leadership: Donald Trump and the American Presidency." International Affairs 96(2):383-400.

Drutman, Lee. 2020. "America Is Now the Divided Republic the Framers Feared." The Atlantic, January 2.

Edsall, Thomas B. 2020. "Why Trump Persists." The New York Times, January 22.

Fraser, Cary. 2000. "Crossing the Color Line in Little Rock: The Eisenhower Administration and the Dilemma of Race for U.S. Foreign Policy." Diplomatic History 24(2):233-64.

Fraser, Cary. 2015. "Donald Trump and the Republican Descent Into Xenophobia.” Truthout, October 11.

Gardels, Nathan. 2018. "Corporate Concentration Threatens American Democracy." New Perspectives Quarterly 35(4):2-5.
Gerson, Michael Gerson closeMichael. 2019. "Which Is Worse, Bigotry or Cowardice in the Face of Bigotry?" Washington Post, December 12.

Goldgeier, James, and Elizabeth N. Saunders. 2018. "The Unconstrained Presidency: Checks and Balances Eroded Long Before Trump." Foreign Affairs, September.

Greenstein, Prof Fred I. 1994. The Hidden-Hand Presidency: Eisenhower as Leader. Johns Hopkins P ed. edition. Baltimore, Md: The Johns Hopkins University Press.

Heersink, Boris, and Jeffery A. Jenkins. 2020. "The Republican Party Is White and Southern. How Did That Happen?" Washington Post, February 7.

Hofstadter, Richard. 1964. "The Paranoid Style in American Politics.” Harper's Magazine, November 1.

Hurd, Richard. 2006. "Reflections on PATCO's Legacy: Labor's Strategic Challenges Persist.” Employee Responsibilities and Rights Journal 207-14.

Inwood, Joshua F. 2015. "Neoliberal Racism: The 'Southern Strategy' and the Expanding Geographies of White Supremacy." Social and Cultural Geography 16(4):407-23.

Kamarck, Elaine. 2020. "Trump's Failed Presidency." Brookings. Retrieved March 29, 2020 (https:// www.brookings.edu/blog/fixgov/2020/03/16/ trumps-failed-presidency/).

Kazin, Michael. 2018. "America’s Never-Ending Culture War." The New York Times, August 24.

King, Desmond, and Stephen Tuck. 2007. "De-Centring the South: America's Nationwide White Supremacist Order after Reconstruction." Past \& Present 194(1):213-53.

Kotlowski, Dean J. 1998. "Richard Nixon and the Origins of Affirmative Action." The Historian 60(3):523-41.

MacLean, Nancy. 2017. Democracy in Chains: The Deep History of the Radical Right's Stealth Plan for America. Reprint edition. Penguin Books.

Mathis, Joel. 2019. "The Most Consequential Politician of the Decade.” December 26.

Maxwell, Angie. 2019. "What We Get Wrong about the Southern Strategy.” Washington Post, July 26.

Mayer, Jeremy D. 2002. "Nixon Rides the Backlash to Victory: Racial Politics in the 1968 Presidential Campaign." The Historian 64(2):351-66. 
Michael, Rosenwald. 2017. "The Ku Klux Klan Was Dead. The First Hollywood Blockbuster Revived It." Washington Post, August 12.

Morone, James. 2019. "Still Crazy After All These Years." March 27.

Myrdal, Gunnar. 1995. An American Dilemma: The Negro Problem and Modern Democracy, Volume 1. 1 edition. New Brunswick, NJ: Routledge.

Naftali, Timothy. 2020a. "The Wounded Presidency, Part One." January 30.

Naftali, Timothy. 2020b. “The Wounded Presidency, Part Two." January 30.

Nixon, Richard. 1957. "The Emergence of Africa: Report to President Eisenhower by Vice President Nixon." Department of State Bulletin 36 635-40.

Roper, Jon. 2004. “'The Contemporary Presidency': George W. Bush and the Myth of Heroic Presidential Leadership." Presidential Studies Quarterly 34(1):132-42.

Sabato, Larry J. 2014. "How Goldwater Changed Campaigns Forever.” POLITICO Magazine, October 27.

Serwer, Adam. 2019. "Trump Tells America What Kind of Nationalist He Is." The Atlantic, July 15.

Shklar, Judith N. 1998. American Citizenship: The Quest for Inclusion. Fourth Printing edition. Cambridge, Mass.: Harvard University Press.

Sinha, Manisha. 2019. "Donald Trump, Meet Your Precursor." The New York Times, November 29.

Smith, Richard Norton. 2014. “Nelson Rockefeller's Last Stand.” POLITICO Magazine, October 21.

Tavernise, Sabrina. 2018. "Why the Announcement of a Looming White Minority Makes Demographers Nervous." The New York Times, November 22.

The Editorial Board. 2018. "America Started Over Once. Can We Do It Again?” The New York Times, July 3.

Todd, Michael L. 2018. "Perspective | The United States Isn't a Democracy — and Was Never Intended to Be." Washington Post, November 6.

Williams, Daniel K. 2010. “Jerry Falwell's Sunbelt Politics: The Regional Origins of the Moral Majority." Journal of Policy History 22(2):125-47.

Wittes, Benjamin, and Susan Hennessey. 2020. "The Disintegration of the American Presidency." The Atlantic, January 21.

Wright, Robin. 2019. "The Rhetoric and Reality of Donald Trump's Racism.” The New Yorker, July 31.
Young, Neil J. 2014. "Worse than Cancer and Worse than Snakes': Jimmy Carter's Southern Baptist Problem and the 1980 Election." Journal of Policy History 26(4):479-508.

Zelizer, Julian E. 2016. "The Power That Gerrymandering Has Brought to Republicans." Washington Post, June 17.

Zwiers, Maarten. 2019. “The Whistles of George Wallace: Gender and Emotions in the 1968 Presidential Campaign." European Journal of American Studies 14(14-1). 